\title{
Influence of Amino Acids on Growth and Cell Wall Composition of Methanobacteriales
}

\author{
By H. KÖNIG \\ Lehrstuhl für Mikrobiologie der Universität Regensburg, D-8400 Regensburg, \\ Federal Republic of Germany
}

(Received 24 May 1985; revised 13 August 1985)

Methanogenic bacteria with pseudomurein sacculi incubated with elevated concentrations of amino acids showed growth inhibition, changes in morphology and, under certain conditions, lysis. Methanobacterium thermoautotrophicum incorporated the amino acids glycine, threonine, ornithine and, in small amounts, aspartic acid into the sacculi, but not $\mathrm{D}$-alanine, mesodiaminopimelic acid or the amino sugar galactosamine.

\section{INTRODUCTION}

Analogues of amino acids that build up the peptide moiety of the murein of eubacteria can interfere with the biosynthesis of peptidoglycan. These analogues either inhibit specific enzymes or replace the corresponding amino acid in the nascent peptidoglycan. A wellinvestigated example of the first group is D-cycloserine, an analogue of $\mathrm{D}$-alanine, which inhibits alanine racemase, $\mathrm{D}$-alanine : $\mathrm{D}$-alanine ligase and $\mathrm{D}$-amino acid transaminase (Strominger $\mathrm{et}$ al., 1960; Neuhaus, 1967). The second group of analogues is represented by glycine (Schleifer et al., 1976; Hammes et al., 1973; for a review see Neuhaus \& Hammes, 1981) and D-serine (Whitney \& Grula, 1964; Trippen et al., 1976). These amino acids can partially replace D-alanine and are incorporated into the nascent peptidoglycan via UDP-activated precursors. Elevated concentrations of these amino acids in the culture medium inhibit the growth of the bacteria, and produce morphological changes and spheroplasts due to a decrease of the cross-linkage of the peptide subunits (reviewed by Neuhaus \& Hammes, 1981).

The ability to take up the amino acids glycine, threonine and isoleucine has been demonstrated for the pseudomurein-containing methanogen Methanobacterium thermoautotrophicum strain Marburg (Gilles et al., 1983; Eikmanns et al., 1983a,b).

This paper describes the influence of elevated concentrations of amino acids on methanogenic bacteria of the order Methanobacteriales.

\section{METHODS}

Organisms and growth conditions. Stock cultures of Methanothermus fervidus (DSM 2088) and Methanobrevibacter arboriphilus (DSM 1125) were gifts from K. O. Stetter and J. Winter, respectively. Methanobacterium thermoautotrophicum strain $\triangle H$ (DSM 1053) was obtained from the Deutsche Sammlung von Mikroorganismen (DSM), Göttingen, FRG. Methanobacterium uliginosum (DSM 2956) is our own isolate. Methanobreribacter arboriphilus $\left(37^{\circ} \mathrm{C}\right)$, Methanobacterium uliginosum $\left(37^{\circ} \mathrm{C}\right.$; König 1984), Methanobacterium thermoautotrophicum $\left(64{ }^{\circ} \mathrm{C}\right)$ and Methanothermus fertidus $\left(84^{\circ} \mathrm{C}\right.$; Stetter et al., 1981) were grown in serum bottles with $\mathrm{H}_{2} / \mathrm{CO}_{2}(80: 20$; $300 \mathrm{kPa}$ ) at 100 r.p.m. or in a 10-litre fermenter (New Brunswick) sparged with $\mathrm{H}_{2} / \mathrm{CO}_{2}(80: 20)$ in medium 1 of Balch et al. (1979), which contains mineral salts, $\mathrm{FeSO}_{4} \cdot 7 \mathrm{H}_{2} \mathrm{O}(0 \cdot 0002 \%)$, sodium acetate $(0 \cdot 25 \%)$, sodium formate $(0.25 \%)$, yeast extract $(0.2 \%)$, Trypticase $(0.2 \%)$, L-cysteine. $\mathrm{HCl}(0.05 \%)$ and $\mathrm{Na}_{2} \mathrm{~S} .9 \mathrm{H}_{2} \mathrm{O}(0.05 \%)$, plus trace elements and vitamins.

Analytical methods. Walls were isolated as described by Schleifer \& Kandler (1967) or in smaller amounts according to Stetter et al. (1981). Amino acids and amino sugars in wall hydrolysates $\left(4 \mathrm{M} \cdot \mathrm{HCl}, 16 \mathrm{~h}, 100^{\circ} \mathrm{C}\right)$ were determined with an amino acid analyser (Biotronik LC 5000) programmed for 'hydrolysates of bacteria' 
(Biotronik). N-terminal amino acids were determined by dinitrophenylation (Takebe, 1965). The occurrence of Dalanine in the walls was tested with D-amino acid oxidase (Boehringer-Mannheim; Larson et al., 1971). C-terminal amino acids were determined by hydrazinolysis (Ghuysen et al., 1966).

Chromatography. The dinitrophenylated amino acids were identified on cellulose thin-layer plates using $1.5 \mathrm{M}-$ potassium phosphate buffer $\mathrm{pH} 6.0$ as solvent. The peptides in partial wall hydrolysates $\left(4 \mathrm{M}-\mathrm{HCl}, 30 \mathrm{~min}, 100{ }^{\circ} \mathrm{C}\right)$ were separated by thin-layer chromatography (TLC) on cellulose thin-layer plates (Polygram CFL 400, Macherey \& Nagel). The following solvents were used: I, $\alpha$-picoline/ammonia/water $(70: 2: 28$, by vol. $) ; 2$, n-propanol/ ammonia/water $(60: 30: 10$, by vol. $) ; 3,75 \%(w / v)$ phenol in water. The running distance was $8 \mathrm{~cm}$.

\section{RESULTS}

\section{Growth in the presence of amino acids}

Growth of the autotrophic methanogen Methanobacterium thermoautotrophicum was tested in the presence of different concentrations of amino acids (Table 1). It grew in $1 \%(\mathrm{w} / \mathrm{v})$ solutions of all amino acids tested. While $3 \%(\mathrm{w} / \mathrm{v})$ solutions of the apolar and polar amino acids glycine, alanine, serine and threonine inhibited growth, $5 \%(\mathrm{w} / \mathrm{v})$ of the acidic amino acids glutamic acid and aspartic acid and more than $5 \%(\mathrm{w} / \mathrm{v})$ of the basic amino acids lysine and ornithine were required for growth inhibition. In contrast, Methanobacterium uliginosum did not grow in the presence of a $0.5 \%(\mathrm{w} / \mathrm{v})$ concentration of the amino acids tested except ornithine, which was inhibitory at concentrations of $1 \%(\mathrm{w} / \mathrm{v})$. When glycine was added to growing cultures of this organism, cells started to lyse. The $\mathrm{OD}_{578}$ decreased after the addition of $1 \%$ glycine (w/v; final concentration) from 0.53 to 0.21 during an incubation period of $33 \mathrm{~h}$. Methanobrevibacter arboriphilus and Methanothermus fervidus grew like Methanobacterium thermoautotrophicum in the presence of $1 \%(\mathrm{w} / \mathrm{v})$ glycine, the only amino acid tested.

\section{Morphology}

Methanobacterium thermoautotrophicum normally occurs in irregular long rods, of ten forming filaments (Zeikus \& Wolfe, 1972). However, in the presence of $1 \%(\mathrm{w} / \mathrm{v})$ glycine most of the cells were highly crooked or coccoid, and the thickness of the walls could be increased up to about fourfold (see also Kandler \& König, 1978). Lysed cells with defective wall structures also occurred. When mannitol $(0.8 \mathrm{M}$, final concentration) together with glycine $(1 \%$, w/v, final concentration) was added to growing cultures of Methanobacterium uliginosum, rod-shaped cells with a very thin $(4-5 \mathrm{~nm})$ pseudomurein layer, or with no such layer, were obtained.

\section{Incorporation of amino acids into the pseudomurein}

Methanobacterium thermoautotrophicum grown in the presence of an amino acid $(1 \%, \mathrm{w} / \mathrm{v})$ normally not present in the wall (König et al., 1982) incorporated glycine, threonine, ornithine and, in smaller amounts, aspartic acid into the pseudomurein (Table 2), while D-alanine, mesodiaminopimelic acid and the amino sugar galactosamine were not used for cell wall biosynthesis (data not shown). Analysis of walls isolated from Methanothermus fervidus and Methanobrevibacter arboriphilus revealed that glycine, the only amino acid tested, could be used as a cell wall constituent (Table 2). This was also true for Methanobacterium uliginosum (data not shown).

In order to determine the position of glycine in the peptide moiety, the walls of Methanohacterium thermoautotrophicum were subjected to dinitrophenylation, hydrazinolysis and partial acid hydrolysis. Glutamic acid $(41 \%)$, alanine $(12 \%)$ and $\varepsilon-\mathrm{NH}_{2}$-lysine $(12 \%)$ were found to be the $\mathrm{N}$-terminal amino acids and glutamic acid $(0 \cdot 16 \%)$, glycine $(17 \%)$, alanine $(3.7 \%)$ and lysine $(1.4 \%)$ the $\mathrm{C}$-terminal amino acids. The $\mathrm{N}$-terminal glutamic acid residues are increased in glycine-containing walls compared to normal walls (König et al., 1982). In addition, a peptide was isolated from partial acid hydrolysates with $R_{F}$ values of $0.39,0.53$ and 0.51 in solvent systems 1, 2 and 3, respectively, and an $R_{\mathrm{NH}_{3}}$ value of 0.94 on the amino acid analyser. It was composed of glycine, alanine and lysine in a molar ratio of $1 \cdot 20: 1 \cdot 23: 1.00$ determined after acid hydrolysis. The hydrolysis products of the dinitrophenylated peptide were glycine, DNPalanine and $\alpha$-DNP-lysine, indicating that the peptide has the primary structure $\varepsilon$-Ala-Lys-Gly. Thus the C-terminal position of glutamic acid (König et al., 1982) is partially substituted by glycine, but this amino acid is also incorporated in other positions of the peptide moiety. 
Table 1. Growth of Methanobacterium thermoautotrophicum in the presence of elevated concentrations of amino acids

The experiments were done in triplicate; representative results are shown.

\begin{tabular}{|c|c|c|c|c|c|}
\hline \multirow{3}{*}{$\begin{array}{l}\text { Amino } \\
\text { acid }\end{array}$} & \multirow{3}{*}{$\begin{array}{l}\text { Concn } \\
(\% / w / v)\end{array}$} & \multicolumn{4}{|c|}{ Growth $\underbrace{\left(\mathrm{OD}_{s>8}\right)}$} \\
\hline & & \multicolumn{4}{|c|}{ Incubation time $(\mathrm{h})$ : } \\
\hline & & 0 & 24 & 47 & 72 \\
\hline Control* & & 0.03 & $0 \cdot 69$ & $1 \cdot 04$ & $1 \cdot 35$ \\
\hline \multirow[t]{2}{*}{ Ala } & 1 & 0.02 & 0.26 & 0.72 & $1 \cdot 17$ \\
\hline & 3 & 0.02 & 0.05 & $0 \cdot 05$ & 0.04 \\
\hline \multirow[t]{3}{*}{ Asp } & 1 & 0.03 & 0.47 & $1 \cdot 04$ & $1 \cdot 40$ \\
\hline & 3 & 0.02 & $0 \cdot 16$ & 0.81 & $1 \cdot 34$ \\
\hline & 5 & 0.01 & $0 \cdot 02$ & $0 \cdot 03$ & 0.03 \\
\hline \multirow[t]{4}{*}{ Glu } & 1 & 0.04 & 0.44 & 0.98 & $1 \cdot 29$ \\
\hline & 3 & $0 \cdot 02$ & 0.11 & 0.58 & $1 \cdot 16$ \\
\hline & 5 & 0.04 & 0.04 & $0 \cdot 06$ & 0.07 \\
\hline & 10 & 0.05 & $0 \cdot 04$ & $0 \cdot 04$ & 0.04 \\
\hline \multirow[t]{2}{*}{ Gly } & 1 & 0.03 & 0.75 & $1 \cdot 12$ & 1.69 \\
\hline & 3 & 0.02 & 0.04 & 0.03 & 0.03 \\
\hline \multirow[t]{4}{*}{ Lys } & 1 & $0 \cdot 03$ & $0 \cdot 24$ & 0.95 & $1 \cdot 19$ \\
\hline & 3 & $0 \cdot 02$ & $0 \cdot 26$ & 0.69 & 0.75 \\
\hline & 5 & 0.01 & 0.03 & 0.06 & 0.11 \\
\hline & 10 & 0.03 & 0.04 & $0 \cdot 04$ & 0.04 \\
\hline \multirow[t]{4}{*}{ Orn } & 1 & $0 \cdot 03$ & 0.53 & $1 \cdot 19$ & $1 \cdot 57$ \\
\hline & 3 & 0.03 & 0.27 & 0.92 & $1 \cdot 24$ \\
\hline & 5 & $0 \cdot 02$ & $0 \cdot 02$ & $0 \cdot 06$ & 0.13 \\
\hline & 10 & 0.04 & 0.03 & 0.03 & 0.04 \\
\hline \multirow[t]{3}{*}{ Ser } & $0 \cdot 5$ & 0.03 & $0 \cdot 12$ & 0.44 & 0.86 \\
\hline & 1 & 0.03 & $0 \cdot 11$ & $0 \cdot 14$ & 0.03 \\
\hline & 3 & 0.02 & $0 \cdot 03$ & 0.08 & 0.02 \\
\hline \multirow[t]{3}{*}{ Thr } & $0 \cdot 5$ & 0.02 & 0.44 & 1.01 & $1 \cdot 21$ \\
\hline & 1 & 0.02 & $0 \cdot 20$ & 0.27 & 0.30 \\
\hline & 3 & 0.03 & $0 \cdot 04$ & 0.08 & 0.02 \\
\hline
\end{tabular}

* Medium 1 of Balch et al. (1979). The amino acids were added to the medium before inoculation.

Table 2. Amino acid composition of the pseudomurein after growth of the cells in the presence of different amino acids

The experiments were repeated two or three times; representative results are shown.

\begin{tabular}{|c|c|c|c|c|c|c|c|c|c|}
\hline \multirow[b]{2}{*}{ Species } & \multirow{2}{*}{$\begin{array}{l}\text { Amino } \\
\text { acid } \\
\text { added }\end{array}$} & \multicolumn{8}{|c|}{ Cell wall composition (molar ratio) ${ }^{*}$} \\
\hline & & Asp & Glu & Ala & Lys & GlcN & Gly & Orn & Thr \\
\hline $\begin{array}{l}\text { Methanobacterium } \\
\text { thermoautotrophicum }\end{array}$ & Gly & ND & $2 \cdot 41$ & $1 \cdot 31$ & $1 \cdot 00$ & 1.55 & 0.47 & ND & ND \\
\hline & Thr & ND & 1.59 & $0 \cdot 43$ & $1 \cdot 00$ & $0 \cdot 70$ & ND & ND & $0 \cdot 29$ \\
\hline & Asp & $0 \cdot 10$ & 1.78 & 0.54 & $1 \cdot 00$ & 0.83 & ND & ND & ND \\
\hline & Orn & ND & $2 \cdot 69$ & $1 \cdot 51$ & $1 \cdot 00$ & $1 \cdot 54$ & ND & $0 \cdot 49$ & ND \\
\hline Methanothermus fervidus & Gly & ND & $2 \cdot 76$ & 0.96 & $1 \cdot 00$ & $0.78 \dagger$ & $0 \cdot 89$ & ND & ND \\
\hline $\begin{array}{l}\text { Methanobrevibacter } \\
\text { arboriphilus }\end{array}$ & Gly & ND & $2 \cdot 10$ & $0 \cdot 88$ & $1 \cdot 00$ & $0.53 \ddagger$ & $0 \cdot 36$ & ND & ND \\
\hline
\end{tabular}

ND, Not detected.

* For the normal cell wall composition of Methanobacteriales see König et al. (1982) and König (1984).

$\dagger$ Containing $31 \mathrm{~mol} \%$ GalN.

†alN. 


\section{DISCUSSION}

The incorporation of different amino acids into the pseudomurein by the autotrophic methanogenic bacteria Methanobacterium thermoautotrophicum strain $\Delta \mathrm{H}$, Methanothermus fervidus and Methanobrevibacter arboriphilus shows that members of three genera of Methanobacteriales can take up amino acids on a large scale from the culture medium. In methanogenic habitats like the rumen or sewage sludge, where high concentrations of amino acids may temporarily occur, the amino acids can probably be used as a cell carbon source. Eikmanns et al. (1983a) pointed out that the mechanism of amino acid uptake by Methanobacterium thermoautotrophicum is probably not facilitated diffusion or active transport because relatively high concentrations $(10 \mathrm{~mm})$ are necessary for maximal rates of incorporation. On the other hand, it is well known that eubacteria can re-use D-alanine from the outside of the cytoplasmic membrane which is released from precursors during murein synthesis (Schwartz et al., 1959). Such re-utilization of D-alanine plays an important role in the cellular economy (Neuhaus \& Hammes, 1981). Methanobacterium thermoautotrophicum also releases L-alanine during growth and cell wall synthesis (Schönheit \& Thauer, 1980), but this methanogen seems not to possess a transport system for L-alanine, which prevents the accumulation of L-alanine in the culture medium (Schönheit \& Thauer, 1980).

The lack of, or very low, incorporation into the pseudomurein of some of the tested compounds, e.g. aspartic acid, may not be due to a higher specificity of the corresponding ligases; the uptake may be too low for measurable incorporation to be obtained, as is the case for glutamic acid (Gilles et al., 1983). Some enzymes, e.g. the ligases of eubacteria and, as shown here, the equivalent enzymes of methanogenic archaebacteria, which are involved in wall biosynthesis do not appear to have a high specificity for a particular amino acid. This raises the question as to how during cell wall biosynthesis the correct amino acid is incorporated, because among the methanogenic bacteria only one example is known, where two amino acids can replace each other. This occurs in Methanobrevibacter ruminantium, where threonine can partly or completely replace alanine (König et al., 1982).

The methanogens tested here varied in their behaviour in the presence of elevated concentrations of amino acids, although all exhibited changes in morphology, probably due to a disturbance of cell wall biosynthesis. The most sensitive species was Methanobacterium uliginosum, isolated from a marshy soil (König, 1984). It did not grow in the presence of a $0.5 \%$ $(\mathrm{w} / \mathrm{v})$ concentration of most of the amino acids tested, and addition of $1 \%(\mathrm{w} / \mathrm{v})$ glycine to growing cultures caused lysis. However, the lysis could be prevented by the addition of mannitol. The resulting stabilized cells without or with a very thin pseudomurein layer may be useful for studies of membrane functions. The fact that different amino acids can be incorporated into the pseudomurein may also be helpful in the study of the de novo synthesis of pseudomurein in vitro.

This paper is dedicated to Prof. Dr Otto Kandler on the occasion of his 65th birthday.

The excellent technical assistance of Roswitha Semmler is acknowledged. I thank K. O. Stetter and T. Langworthy for critical reading of the manuscript and $\mathrm{K}$. O. Stetter and $\mathbf{J}$. Winter for the stock cultures. This work was supported by the Deutsche Forschungsgemeinschaft (Ko 785/1-2).

\section{REFERENCES}

Balch, W. E., Fox, G. E., Magrum, L. J., Woese, C. R. \& WOLFE, R. S. (1979). Methanogens: reevaluation of a unique biological group. Microbiological Reviews 43, 260-296.

Eikmanns, B., Jaenchen, R. \& Thauer, R. K. $(1983 a)$. Propionate assimilation by methanogenic bacteria. Archives of Microbiology 136, 106-110.

Eikmanns, B., Linder, D. \& Thauer, R. K. (1983b). Unusual pathway of isoleucine biosynthesis in Methanobacterium thermoautotrophicum. Archives of Microbiology 136, 111-113.

Ghuysen, J. M., Tipper, D. J. \& Strominger, J. L. (1966). Enzymes that degrade bacterial cell walls. Methods in Enzymology 8, 685-699.

Gilles, H., Jaenchen, R. \& Thauer, R. K. (1983). Biosynthesis of 5-aminolevulinic acid in Methanobacterium thermoautotrophicum. Archives of Microbiology 135, 237-240.

Hammes, W. P., Schleifer, K. H. \& Kandler, O. (1973). Mode of action of glycine on the biosynthesis of peptidoglycan. Journal of Bacteriology 116, 10291053 . 
KaNDLER, O. \& KöNIG, H. (1978). Chemical composition of the peptidoglycan-free cell walls of methanogenic bacteria. Archices of Microbiology 118, 141152.

KöNIG, H. (1984). Isolation and characterization of Methanobacterium uliginosum sp. nov. from a marshy soil. Canadian Journal of Microbiology 30, 14771481.

König, H., Kralik, R. \& Kandler, O. (1982). Structure and modifications of pseudomurein of Methanobacteriales. Zentralblatt für Bakteriologie. Microbiologie und Hygiene, I Abteilung, Originale C 3, 179-191.

Larson, D. M., Setsinger, D. C., \& Waibel, P. E. (1971). Procedure for determination of D-amino acids. Analytical Biochemistry 39, 395-401.

Neuhaus, F. C. (1967). D-Cycloserine and $O$-carbamoyl-D-serine. In Antibiotics: Mechanism and Action, vol. I, pp. 40-83. Edited by D. Gottlieb \& P. D. Shaw. Heidelberg: Springer Verlag.

Neuhaus, F. C. \& Hammes, W. P. (1981). Inhibition of cell wall biosynthesis by analogues of alanine. In Pharmacology and Therapeutics, vol. 14, pp. 265-319. Edited by D. J. Tipper. Oxford: Pergamon Press.

SChleifer, K. H. \& KandleR, O. (1967). Zur chemischen Zusammensetzung der Zellwand der Streptokokken. I. Die Aminosäuresequenz des Mureins von Streptococcus thermophilus und Streptococcus faecalis. Archives of Microbiology 57, 335-364.

Schleifer, K. H., Hammes, W. P. \& Kandler, O. (1976). Effect of endogenous and exogenous factors on the primary structures of bacterial peptidoglycan. Advances in Microbial Physiology 13, 245-292.

SChönheit, P. \& Thauer, R. K. (1980). L-Alanine, a product of cell wall synthesis in Methanobacterium thermoautotrophicum FEMS Microbiology Letters $\mathbf{9}$, $77-80$.

SchWartz, J. H., MaAs, W. K. \& Simon, E. J. (1959) An impaired concentrating mechanism for amino acids in mutants of Escherichia coli resistant to Lcanavanine and D-serine. Biochimica et biophysica acta 32, 582-583.

STETTER, K. O. THOMM, M., WINTER, J., WILDGRUBER, G., Huber, H., Zillig, W., Janecovic, D., KöNIG, H., Palm, P. \& Wunderl, S. (1981). Methanothermus feridus, sp. nov., a novel extremely thermophilic methanogen isolated from an Icelandic hot spring. Zentralblatt für Bakteriologie, Mikrobiologie und Hygiene, I Abteilung, Originale C 2, 166-178.

Strominger, J. L., Ito, E. \& ThrenN, R. H. (1960). Competitive inhibition of enzymatic reactions by oxamycin. Journal of the American Chemical Society 82, 998-999.

TAKEBE, J. (1965). Extent of cross linkage in the murein sacculus of Escherichia coli B cell wall. Biochimica et biophysica acta 101, 124-126.

Trippen, B., Hammes, W. P., Schleifer, K. H. \& KaNDLER, O. (1976). Die Wirkung von D-Aminosäuren auf die Struktur und Biosynthese des Peptidoglycans. Archives of Microbiology 109, 247-261.

Whitney, J. G. \& GRULA, E. A. (1964). Incorporation of D-serine into the cell wall mucopeptide of Micrococcus lysodeikticus. Biochemical and Biophysical Research Communications 14, 375-381.

ZEIKUS, J. G. \& WolfE, R. S. (1972). Methanobacterium thermoautotrophicum sp. n., an anaerobic, autotrophic, extreme thermophile. Journal of Bacteriology 109, 707-713. 